\title{
BOVINE TUBERCULOSIS IN THE REPUBLIC OF MACEDONIA: POSTMORTEM, MICROBIOLOGICAL AND MOLECULAR STUDY IN SLAUGHTERED REACTOR CATTLE
}

\author{
Iskra Cvetkovikj, Slavcho Mrenoshki, Kiril Krstevski, Igor Djadjovski, \\ Branko Angjelovski, Zagorka Popova, Aleksandar Janevski, \\ Aleksandar Dodovski, Aleksandar Cvetkovikj \\ Veterinary Institute, Faculty of Veterinary Medicine, Ss. Cyril and Methodius \\ University in Skopje, Lazar Pop Trajkov 5-7, 1000 Skopje, Republic of Macedonia
}

Received 1 July 2016; Received in revised form 29 November 2016; Accepted 2 December 2016

\begin{abstract}
Bovine tuberculosis is a chronic infectious disease in cattle caused mainly by Mycobacterium bovis and to a lesser extent by Mycobacterium caprae. The other members of the Mycobacterium tuberculosis complex (MTBC) can also cause the disease in domestic and wild animals and all of them have a zoonotic potential. The main purpose of the study was to determine the presence and distribution of the tuberculous lesions in reactor cattle, and to isolate and identify the causative agents of bovine tuberculosis in the Republic of Macedonia. Lymph nodes and affected organs from 188 reactor cattle slaughtered due to a positive intradermal comparative cervical tuberculin test were analyzed by detection of tuberculous lesions, followed by isolation and molecular identification of the isolated mycobacteria. The isolation was performed on selective media Lowenstein Jensen with glycerol, Lowenstein Jensen without glycerol and Stonebrink medium supplemented with pyruvate. The molecular identification of the MTBC members was performed by analysis of the Regions of difference (RD1, RD9 and RD4) and detection of single nucleotide polymorphisms in the lepA gene for Mycobacterium caprae. Typical tuberculous lesions were detected in 62 animals (33.0\%) and the lesions were most prevalent in the mediastinal lymph nodes (47.5\%). The isolated mycobacteria in the MTBC were identified as Mycobacterium bovis and Mycobacterium caprae and were found in both animals with visible lesions (82.2\%) and animals without visible lesions (27.7\%). The slaughterhouse postmortem examinations and laboratory investigations should be included on regular bases in order to improve the National eradication program.
\end{abstract}

Key words: bovine tuberculosis, Mycobacterium bovis, Mycobacterium caprae, PCR, Republic of Macedonia

\section{INTRODUCTION}

Bovine tuberculosis (bTB) is an infectious chronic disease of cattle worldwide. Besides cattle, the causative agents of bTB can affect other domestic animals, a wide variety of wildlife species and humans (1). Although the disease in cattle is mainly caused by Mycobacterium bovis (M. bovis) and to a lesser extent by Mycobacterium

Corresponding author: Assist. Prof. Iskra Cvetkovikj, $\mathrm{PhD}$

E-mail address: iskra@fvm.ukim.edu.mk

Present address: Veterinary Institute, Faculty of Veterinary Medicine,

Ss. Cyril and Methodius University in Skopje,Lazar Pop Trajkov 5-7,

1000 Skopje, Republic of Macedonia

Phone: +38923240751 ; Fax: +38923114619

Mobile: +38978200422

Copyright: $\odot 2016$ Cvetkovikj I. This is an open-access article published under the terms of the Creative Commons Attribution License which permits unrestricted use, distribution, and reproduction in any medium, provided the original author and source are credited.

Competing Interests: The authors have declared that no competing interests exist.

Available Online First: 15 December 2016

Published on: 15 March 2017

http://dx.doi.org/10.1515/macvetrev-2016-0097 caprae (M. caprae) (2), according to the Task Force Bovine Tuberculosis Subgroup (3), bovine tuberculosis is the "Infection in cattle with any of the disease causing mycobacterial species within the Mycobacterium tuberculosis complex". Despite the differences in host specificity, the members of the Mycobacterium tuberculosis complex (MTBC) have $99.9 \%$ similarity at a nucleotide level and an identical 16s rRNA sequence (4).

Bovine tuberculosis is endemic in many European countries and has a major impact on their economy and agricultural industries (5). The disease has a significant public health importance, especially in developing countries where the burden of $M$. bovis infection in humans is important, having in mind the close habitat of the animals and humans, HIV/AIDS condition, consumption of nonpasteurized milk and milk products and the level of veterinary control (6). According to Muller et al. (7), zoonotic tuberculosis in Europe is represented 
by a median proportion of $0.4 \%(0 \%-21.1 \%)$ of $M$. bovis and $M$. caprae in all bacteriologically confirmed human cases, whereas for Africa the median proportion is $2.8 \%(0 \%-37.7 \%)$.

Republic of Macedonia (RM) is a non Officialy Tuberculosis Free (nonOTF) country and despite the eradication program in force, the disease has been present for many decades. According to Gramatikovski and Stojanovski (8), the first written data dates from 1926 when the disease was first diagnosed in imported cattle. According to Nikolovski et al. (9), in the period from 2007 till 2009, bTB was diagnosed (by intradermal comparative cervical tuberculin test) in $0.24 \%$ of the tested cattle. The baseline of the eradication program is the test and slaughter policy (10). The testing is performed by an intradermal single cervical test (ISCT), which if positive or suspicious is followed by an intradermal comparative cervical test (ICCT). All cattle that have reacted positive to ICCT are slaughtered, but post mortem inspection and laboratory confirmation are not regularly conducted. So far, the data from the tuberculin skin test are the only diagnostic criteria that certify the presence of bTB in RM, which indicates a lack of scientific evidence about the etiology and epidemiology of the disease. Considering this, the aims of this study were to determine the presence and distribution of typical tuberculous lesions in reactor cattle and to isolate and identify the causative agents of bTB in RM.

\section{MATERIAL AND METHODS}

\section{Sample collection}

The study was conducted on cattle slaughtered due to a positive reaction on an ICCT as part of the National eradication program in 2011, 2012 and 2013. The samples originated from 188 animals from 101 holdings in 18 epidemiological units (municipalities) in RM. The number and origin of the samples are shown in Table 1.

One-hundred-and-forty-five samples (77\%) originated from 95 different holdings where the animals were condemned due to one outbreak. Twenty four samples $(12,7 \%)$ were collected from animals derived from 5 holdings due to two outbreaks. Nineteen samples $(10 \%)$ originated from animals confiscated for slaughter from one holding (herd with chronic bTB) during the three year research period.

The samples were collected during slaughtering of the animals and consisted of the retropharyngeal (RLNs), mediastinal (MdLNs), and mesenteric (MsLNs) lymph nodes (regardless of the presence or absence of lesions). Also, if pathological changes on the lungs, liver or other organs were present, those organs were sampled as well. The samples

Table 1. Number and origin of the tested samples

\begin{tabular}{cccc}
\hline Region & Municipality & No. of holdings & No. of samples \\
\hline Kumanovo & Kumanovo & 17 & 31 \\
Kumanovo & S.Nagoricane & 6 & 6 \\
Skopje & Aracinovo & 5 & 9 \\
Skopje & Ilinden & 4 & 16 \\
Skopje & Sopiste & 2 & 5 \\
Skopje & GaziBaba & 1 & 9 \\
Skopje & Petrovec & 4 & 8 \\
Skopje & Saraj & 1 & 1 \\
Tetovo & Tearce & 1 & 1 \\
Tetovo & Tetovo & 35 & 68 \\
Tetovo & Zelino & 6 & 6 \\
Tetovo & Bogovinje & 1 & 2 \\
Tetovo & Brvenica & 5 & 10 \\
Gostivar & Gostivar & 6 & 8 \\
Bitola & Bitola & 4 & 5 \\
Sv. Nikole & Sv. Nikole & 1 & 1 \\
Prilep & Prilep & 1 & 1 \\
Veles & Veles & 1 & 1 \\
Total & & $\mathbf{1 0 1}$ & $\mathbf{1 8 8}$ \\
\hline
\end{tabular}


were transported (at $+4^{\circ} \mathrm{C}$ ) and processed in the laboratories of the Faculty of Veterinary Medicine in Skopje. The samples were longitudinally sliced on $5 \mathrm{~mm}$ thick slices and the presence of tuberculous lesions was recorded.

\section{Isolation of mycobacteria}

For bacteriological testing, the sampled organs from one animal were pooled and processed by homogenization, decontamination and concentration, and were inoculated on selective media [Lowenstein Jensen (LJ) with glycerol (Biolife, Italy), LJ without glycerol (Oxoid, UK) and Stonebrink medium supplemented with pyruvate (Oxoid, UK)] as previously described $(11,12,13)$. The incubation was in aerobic atmosphere, at $37^{\circ} \mathrm{C}$ for 12 weeks. In case of contamination, the procedure was repeated. Colonies with pale yellow color and dysgonic growth that appeared after min. 4 weeks of incubation were classified as suspect colonies and were further processed by molecular methods.

\section{Molecular identification}

The extraction of the mycobacterial DNA from the suspect colonies using PureLinkGenomic DNA Kit (Thermo Fisher Scientific Inc.) was performed according to the producer's manual. The molecular detection and identification of the mycobacteria was based on the presence of the $16 \mathrm{~S}$ rRNA, as well as the presence or absence of RD9, RD1 and RD4 by SybrGreenPCR and melting curve analysis, as previously described (14). Briefly, the detection and identification was divided into two reactions performed simultaneously. The first reaction was able to detect $16 \mathrm{~S}$ rRNA (genus Mycobacterium), RD9 present (RD9+) for M. tuberculosis and RD1 absent (RD1-) for $M$. bovis BCG. In the second reaction, if RD4 absent (RD4-) was detected, the isolate was classified as $M$. bovis. In case that RD4 present (RD4+) was detected, the isolate was classified as member of the group of $M$. caprae, M.africanum, M. pinipedii or M. microti. During this study, Domogalla et al. (15) detected RD4isolates of $M$. caprae. Considering this, the isolates were further identified by the presence of specific single nucleotide polimorfisms (SNPs) in the lepA gene by the previously described protocols $(15,16)$.

\section{RESULTS}

Typical tuberculous lesions (Fig. 1, 2 and 3) were detected in 62 animals (33\%). Generalized bTB was diagnosed in 3 animals.

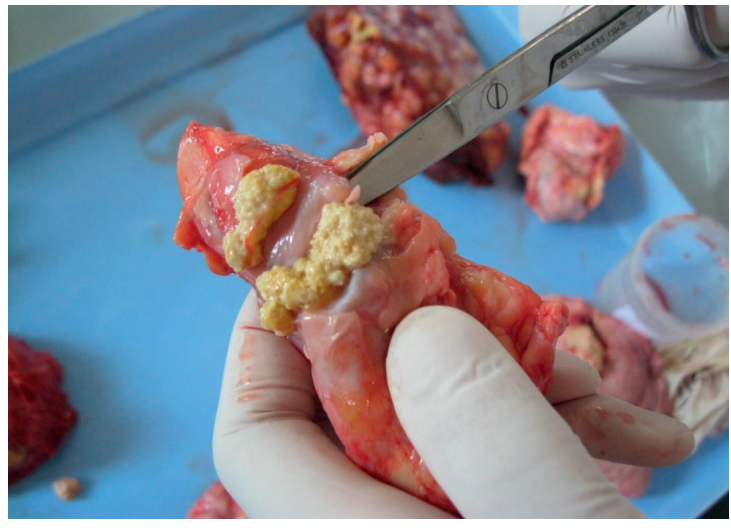

Figure 1. Caseous necrosis in a mediastinal lymph node

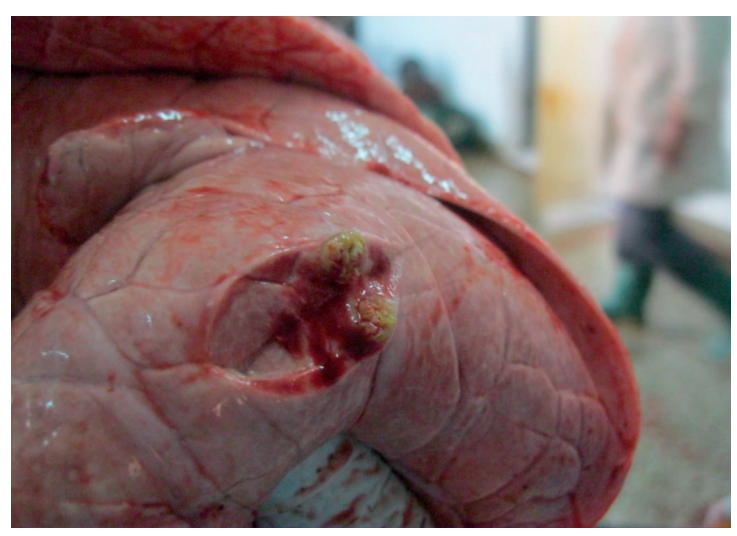

Figure 2. Tubercle in lungs

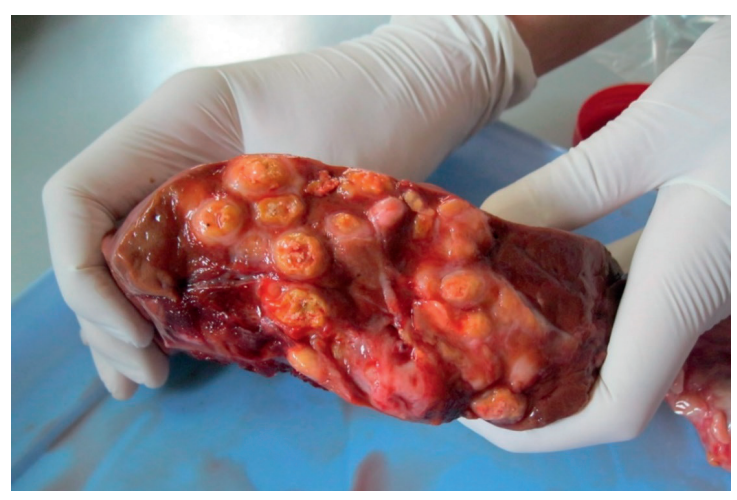

Figure 3. Multiple tubercles in lungs

The distribution of the visible lesions from the sampled animals is shown in Table 2 and the prevalence of visible lesions per organ in Table 3 . The highest prevalence of tuberculous lesions in the lymph nodes was $47.47 \%$, detected in MdLNs (CI 95\%: 37.63-57.31\%) and the lowest was 9.09\%, detected in the MsLNs (CI 95\%: 3.43-14.75\%). 
Table 2. Distribution of visible lesions from the sampled animals

\begin{tabular}{lc}
\hline \multicolumn{1}{c}{$\begin{array}{c}\text { Distribution of } \\
\text { visible lesions }\end{array}$} & $\begin{array}{c}\text { Animals } \\
\text { with visible } \\
\text { lesions }\end{array}$ \\
\hline Rethropharingeal LNs* & 9 \\
Mediastinal LNs & 26 \\
Mesenterial LNs & 2 \\
Lung & 1 \\
Rethropharingeal LNs/Mediastinal LNs/Lungs & 3 \\
Rethropharingeal LNs/Mediastinal LNs & 5 \\
Rethropharingeal LNs/Lungs & 2 \\
Retrophariengeal LNs/Mediastinal LNs/ & 1 \\
Mesenterial LNs & 1 \\
Retrophariengeal LNs/Mesenterial LNs & 7 \\
Mediastinal LNs/Lungs & 2 \\
Mediastinal LNs/Mesenterial LNs & 3 \\
Generalized bTB & $\mathbf{6 2}$ \\
\hline Total & \\
\hline
\end{tabular}

*LNs-Lymph nodes

The bacteriological testing yielded 110 (59\%) colonies with typical morphology for Mycobacterium spp. (Fig. 4). Following extraction, the conserved region in the 16s rRNA gene was amplified in all 110 samples with melting temperature $(\mathrm{Tm}) 79,50-81,60^{\circ} \mathrm{C}$, thus assigning them in the genus Mycobacterium.

Table 3. Percentage of visible lesions per organ

\begin{tabular}{lc}
\hline \multicolumn{1}{c}{ Sample } & $\begin{array}{c}\text { No. of samples with visible } \\
\text { lesions }\end{array}$ \\
\hline Retrophariengeal LNs* & $24 / 99(24.24 \%)$ \\
Mediastinal LNs & $47 / 99(47.47 \%)$ \\
Mesenterial LNs & $9 / 99(9.09 \%)$ \\
Lung & $16 / 99(16.16 \%)$ \\
Liver & $3 / 99(3.03 \%)$ \\
\hline
\end{tabular}

* LNs-Lymph nodes

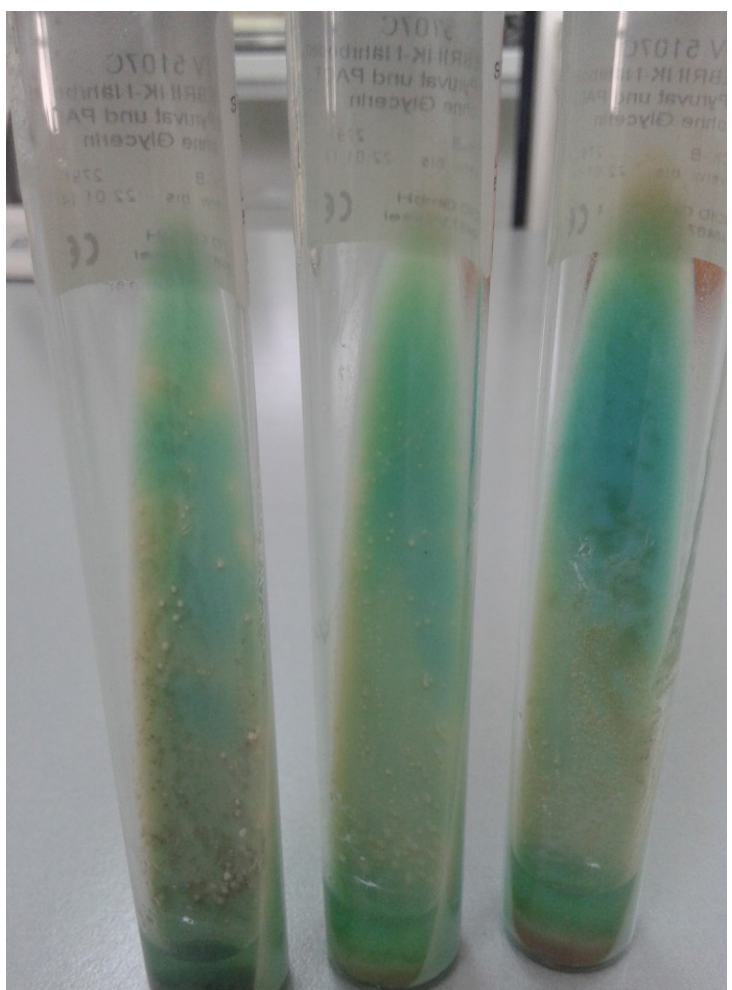

Figure 4. Suspect colonies on Stonebrink medium

RD9+ and RD1- were not present in any of the 110 samples which indicates absence of $M$. tuberculosis or M. bovis BCG. In twenty fours samples, besides the amplification of the genus control product, no RD specific amplicons were observed which points to the fact that those mycobacteria were not part of the MTBC and were classified as nontuberculous mycobacteria (NTM).

Seven samples were characterized as RD4+ group by giving positive result for $\mathrm{RD} 4+(\mathrm{Tm}=77.70$ $78.90^{\circ} \mathrm{C}$ ). In 79 samples, RD4- was amplified and by the melting curve analysis $\left(\mathrm{Tm}=82.50-83.70^{\circ} \mathrm{C}\right)$, M. bovis was confirmed. The controls used in the study were M. tuberculosis H37Rv, M. bovis (supplied by the Croatian Veterinary Institute) and M. caprae (supplied by the Croatian Veterinary Institute). In each reaction, the three controls gave the species specific pattern for RDs.

In the RD4+ isolates, the specific SNPs in the lepA gene for $M$. caprae were amplified and resulted in confirmation of M. caprae. From the 79 RD4- isolates, specific SNPs in the lepA gene for $M$. caprae were amplified in 8 isolates.

In total, 71 isolates were characterized as $M$. bovis and 15 isolates as M. caprae. The Macedonian isolates of $M$. caprae were both $\mathrm{RD} 4+(\mathrm{n}=7)$ and RD4- $(\mathrm{n}=8)$. 
Table 4. Mycobacterial isolates from animals with visible lesions and animals with non-visible lesions

\begin{tabular}{ccccccc}
\hline & $\begin{array}{c}\text { Number of } \\
\text { animals }\end{array}$ & $\begin{array}{c}\text { Mycobacterium } \\
\text { isolate }\end{array}$ & NTM & MTBC & M. bovis & M. caprae \\
\hline Animals with visible lesions & 62 & 58 & 7 & 51 & 43 & 8 \\
Animals with non-visible lesions & 126 & 52 & 17 & 35 & 28 & 7 \\
\hline Total & $\mathbf{1 8 8}$ & $\mathbf{1 1 0}$ & $\mathbf{2 4}$ & $\mathbf{8 6}$ & $\mathbf{7 1}$ & $\mathbf{1 5}$ \\
\hline
\end{tabular}

The prevalence of $M$. bovis isolated from the samples was 37.7\% (CI 95\%: 30.77-44.63\%) and the prevalence of $M$. caprae was 7.9\% (CI 95\%: 4.04$11.76 \%$ ). Mycobacterium bovis, M. caprae and NTM were isolated from both animals with visible lesions and animals with non-visible lesions (Table 4.)

The detailed prevalence of $M$. bovis, $M$. caprae and NTM in the bTB positive regions in RM is shown in Table 5. in tuberculin tests in both Officially Tuberculosis Free countries (somewhere acting as the only bTB diagnostic tool) and nonOTF countries $(17,18)$.

During the slaughterhouse surveillance, we detected visible lesions in 62 animals (33\%) and the prevalence of the lesions was highest in the MdLNs, followed by RLNs and lungs which indicates the respiratory route as a possible mode of infection. These results are similar with those observed by

Table 5. Percentage of isolated M. bovis, M. caprae and NTM in the bTB positive regions

\begin{tabular}{ccccccc}
\hline Region & $\begin{array}{c}\text { No. of } \\
\text { analysed } \\
\text { samples }\end{array}$ & $\begin{array}{c}\text { Mycobacterium } \\
\text { spp. }\end{array}$ & NTM & MTBC positive & M. bovis & M. caprae \\
\hline Kumanovo & 37 & $21 / 37(56.7 \%)$ & $5 / 37(13.5 \%)$ & $16 / 37(43.2 \%)$ & $14 / 16(87.5 \%)$ & $2 / 16(12.5 \%)$ \\
Skopje & 48 & $27 / 48(56.2 \%)$ & $7 / 48(14.5 \%)$ & $20 / 48(41.6 \%)$ & $16 / 20(80 \%)$ & $4 / 20(20 \%)$ \\
Tetovo & 87 & $55 / 87(63.2 \%)$ & $10 / 87(11.5 \%)$ & $45 / 87(51.7 \%)$ & $37 / 45(82.2 \%)$ & $8 / 45(17.7 \%)$ \\
Gostivar & 8 & $4 / 8(50 \%)$ & $0 / 8(0 \%)$ & $4 / 8(50 \%)$ & $3 / 4(75 \%)$ & $1 / 4(25 \%)$ \\
Bitola & 5 & $1 / 5(20 \%)$ & $0 / 5(0 \%)$ & $1 / 5(20 \%)$ & $1 / 1(100 \%)$ & $0 / 1(0 \%)$ \\
Sv. Nikole & 1 & $1 / 1(100 \%)$ & $1 / 1(100 \%)$ & $0 / 1(0 \%)$ & $0 / 1(0 \%)$ & $0 / 1(0 \%)$ \\
Prilep & 1 & $1 / 1(100 \%)$ & $1 / 1(100 \%)$ & $0 / 1(0 \%)$ & $0 / 1(0 \%)$ & $0 / 1(0 \%)$ \\
Veles & 1 & $0 / 1(0 \%)$ & $0 / 1(0 \%)$ & $0 / 1(0 \%)$ & $0 / 1(0 \%)$ & $0 / 1(0 \%)$ \\
\hline Total & $\mathbf{1 8 8}$ & $\mathbf{1 1 0}$ & $\mathbf{2 4}$ & $\mathbf{8 6}$ & $\mathbf{7 1}$ & $\mathbf{1 5}$ \\
\hline
\end{tabular}

\section{DISCUSSION}

This study shows that bTB in the Republic of Macedonia is caused by $M$. bovis and M. caprae. According the data from the Food and Veterinary Agency of RM, bTB in RM during the research period (2011-2013) was diagnosed (by ICCT) in $0.1 \%$ of the tested cattle. The tuberculin skin test is the only diagnostic procedure that the National eradication program in RM relies on. The slaughterhouse surveillance is not performed successively to the slaughter of the reactors (17) which represents a considerable gap in the disease eradication. Slaughterhouse surveillance represents an important component in bTB diagnosis by detection of tuberculous lesions especially in commercial slaughtering and in animals not reacting
Fitzgerald et al. (19), where in adult cattle the typical lesions were predominantly located in the thoracic lymph nodes due to the lateral transmission via an aerosol route. Other authors have also registered the lungs and associated lymph nodes as locations were the tuberculous lesions were most prevalent (20, $21,22)$. This comes from the fact that inhalation is believed to be responsible for $80-90 \%$ of all tuberculosis infections in cattle (20).

Besides the post mortem slaughterhouse surveillance, the laboratory methods (isolation and molecular identification) are not part of the bTB diagnostic and eradication scheme in RM. EU member states, besides the test and slaughter policy in the eradication programs, also implement laboratory investigations in terms of identification of the causative agents in order to confirm 
the disease and to evaluate the ante-mortem diagnostic methods $(23,24,25)$. The isolation and identification of M. bovis and M. caprae in Spain is used to confirm tuberculosis infection in the herd, as well as for withdrawal of the status of herd free of tuberculosis (13).

The results from this research emphasize the need for continuous identification and typing of isolates in reactor animals in order to understand the disease epidemiology. The identification of the members of MTBC can be accomplished by a variety of molecular based assays that target specific regions in the mycobacterial genomes. The RDs or large sequence polymorphisms (LSP) are conserved in the mycobacteria belonging to the MTBC and due to their irrevocable character and intra-lineage consistency are widely used for construction of evolutionary schemes of the complex. $(4,26)$. The evolutionary scenarios suggest that the modern MTBC species evolved from a common ancestor through gaining these irreversible genomic deletions i.e RDs. $(4,27)$. The absence or presence of these genomic deletions can act as a discrimination tool for identification of the MTBC members - fact that has been used for designing and development of variety of PCR assays targeting the RDs. (14, 28, 29, 30). In our approach using the SybrGreenPCR and melting curve analysis as described by Pinsky and Banaei (14), we identified 79 isolates with RD4- and 7 isolates with RD4+. During our research Domogalla et al. (15) reported diversity in the RD4 in alpine $M$. caprae isolates and found three variants of the isolates: Allgau type (conserved RD4), Karwendel type (deletion of $5 \mathrm{~kb}$ ) and Lechtal type (deleted RD4). These variants were also confirmed in Bavarian and Austrian cattle and wildlife (red deer and fox) (31).

Differences in RD4 among $M$. caprae isolates were also reported in the study by Rodriguez et al. (32), where one isolate from a cow of Eastern European origin did not show presence or absence of RD4.

In order to identify whether the RD4- isolates were all $M$. bovis or the Macedonian M. caprae isolates have deleted RD4, all of the RD4- isolates were subjected to the protocol for detection of $M$. caprae specific SNPs in the lepA gene $(15,16)$. From the 79 (RD4-) isolates, 8 isolates were identified as M. caprae. The RD4+ isolates were all confirmed as $M$. caprae with this protocol. This confirms that the Macedonian M.caprae isolates are both RD4+ and RD4-. This illustrates that the deletions in RD4 detected by this protocol are not suitable marker for species differentiation of $M$. bovis and M. caprae in Macedonian $M$. caprae isolates. Besides the RD4 differences, these isolates also have shown differences in certain locuses in the MIRU-VNTR 12 loci typing panel (data not shown).

Mycobacterium bovis and $M$. caprae were isolated from $82.2 \%$ of the animals with visible lesions. The isolation of $M$. bovis and M. caprae for the diagnosis of tuberculosis in animals is usually considered as the golden standard (13). However, being unable to identify $100 \%$ of infected animals, this method cannot be considered as such even in samples with bTB lesions. The sensitivity of the method varies depending of different factors such as sampling procedure, type of samples, sample storage and implemented bacteriology protocols (type of decontamination, culture media) (13) and ranges from $4.7 \%$ to $85 \%(12,33,34,35,36,37)$.

Mycobacterium bovis and $M$. caprae were isolated from $27.7 \%$ animals with non-visible lesions. The isolation of these species from animals with non-visible lesions further contributes to the fact that animals with non-visible lesions does not mean non-infected and non-infectious animals (38). Our findings correspond to the results from a research in Ireland where $M$. bovis was recovered from tissues taken from $19-28 \%$ of the animals with non-visible lesions (39). There are a variety of reasons for the lack of tuberculous lesions in infected animals, such as: early stages of infection, thoroughness of examination during slaughter, location and size of tubercles, prevalence of the disease and number of reactors in the herd $(22,39)$.

Nontuberculous mycobacteria were isolated from $13 \%$ of the animals with non-visible lesions. The culture-negative results could be because of early stages of infection, state of latency or nonspecific sensitization in the tuberculin skin test due to infection with bacteria from non-mycobacterial origin (40).

The highest number of bTB agents were isolated and identified in the region of Tetovo, folowed by Gostivar, Kumanovo, Skopje and Bitola. Both of the mycobacteria were confirmed as causative agents of bTB in Croatia (41), Bosnia and Herzegovina (42), Spain, France, Germany, Italy, Slovenia, Austria, Hungary, Poland (43, 44), England (36), Algeria (45), China (46) and Ethiopia (47).

Over the years and according to the data from the Food and Veterinary Agency of RM (FVA), the northwestern part of the country i.e. the Tetovo region (Tetovo, Zelino, Tearce, Bogovinje and Brvenica) is the part with the highest prevalence of bTB. The persistence of the disease in this part of the country could be as a result of incomplete 
Bovine tuberculosis: postmortem, microbiological and molecular study

depopulation of the reactors in infected herds, lack of movement control, insufficient biosafety measures, inappropriate disinfection or inadequate repopulation of the holdings. This part of the country is bordering with Kosovo and Albania where transboundary movements without proper veterinary control could be an important issue that can contribute to the transmission of the disease between the neighboring countries. None of the neighboring countries of RM is an official tuberculosis free country. Therefore, strengthening of movement control would decrease the risk of the infection importation in the country.

Another aspect that should be taken into consideration is testing of other domestic and wild animals that can act as a true reservoir or a spill over host for cattle as well as humans. This is due to the fact that $M$. bovis can affect a wide variety of species including domestic animals, pets and wildlife reservoirs (deer, wild boar and badger) (2).

Mycobacterium bovis and $M$. caprae are zoonotic pathogens which emphasizes the need for their diagnosis in the human population. In 2012, 25 EU member states reported 125 cases of human tuberculosis due to M. bovis (48). Mycobacterium caprae has also been identified as causative agent of human tuberculosis in Croatia, Germany, Spain and Austria $(41,44,49)$. There are no official data for the presence of $M$. bovis or M. caprae in the human population of RM. According to the information from the National Reference Laboratory for human tuberculosis, the diagnosis is aimed to detect and not to identify a MTBC member, as well as to determine the antibiotic susceptibility of the isolate. Due to this, one can't draw a conclusion about the zoonotic burden of $M$. bovis and $M$. caprae in RM. The fact that human tuberculosis is most prevalent in the northwestern part of the country (same as bTB), definitely draws attention to the need for further investigation and inter-institutional cooperation.

\section{CONCLUSION}

Our study demonstrates that $M$. bovis and $M$. caprae are causative agents of bTB in the Republic of Macedonia, isolated and identified from slaughtered reactor cattle with and without visible tuberculosis lesions. These findings highlight the importance of routine slaughterhouse surveillance and implementation of the laboratory diagnostic procedures for identification and typing of MTBC members as essential tools for a successful eradication program. Future research should be aimed to determine if Macedonian $M$. caprae isolates have varieties in the RD4 on which basis they can be subtyped, as well as to see if the obtained subtypes have a spatial distribution. Knowing the reservoir variety of the $M$. bovis and M. caprae, further research is needed in order to estimate the prevalence of the disease in other domestic and wildlife species.

\section{CONFLICT OF INTEREST STATEMENT}

The authors declared that they have no potential conflict of interest with respect to the authorship and/or publication of this article.

\section{ACKNOWLEDGEMENT}

We would like to thank the colleagues from the Croatian Veterinary Institute for providing the mycobacterial strains.

\section{REFERENCES}

1. O'Reilly, L.M., Daborn, C.J. (1995). The epidemiology of Mycobacterium bovis infections in animals and man. A review. Tuber Lung Dis. 76 (1): $1-46$.

https://doi.org/10.1016/0962-8479(95)90591-X

2. Pesciaroli, M., Alvarez, J., Boniotti, M.B., Cagiola,M.,DiMarcoV.,Marianelli,C.,Pacciarini,M., Pasquali, P. (2014). Tuberculosis in domestic animal species. Res Vet Sci. 97, Suppl. S78-85.

https://doi.org/10.1016/j.rvsc.2014.05.015

PMid:25151859

3. Task force bovine tuberculosis subgroup. Working document on eradication of bovine tuberculosis in the EU accepted by the Bovine tuberculosis subgroup of the Task Force on monitoring animal disease eradication. (2006). SANCO/10200/2006. http:/ec.europa.eu/food/animal/diseases/eradication/ tb_workingdoc2006_en.pdf

4. Brosch, R., Gordon, S., Marmiesse, M., Brodin, P., Buchrieser,C.,Eiglmeier,K.,Garnier, T., Gutierrez,C., Hewinson, G., Kremer, K., Parsons, L., Pym, A., Samper, S., Soolingen, D., Cole, S. (2002). A new evolutionary scenario for the Mycobacterium tuberculosis complex. P Natl Acad Sci USA. 99 (6): 3684-3689.

https://doi.org/10.1073/pnas.052548299

PMid:11891304 PMCid:PMC122584 
5. Schiller, I., Waters, W.R., Vordermeier, H.M., Jemmi, T., Welsh, M., Keck, N., Whelan, A., Gormley, E., Boschiroli, M.L., Moyen, J.L., Vela, C., Cagiola, M., Buddle, B.M., Palmer, M., Thacker, T., Oesch, B. (2011). Bovine tuberculosis in Europe from the perspective of an officially tuberculosis free country: trade, surveillance and diagnostics. Vet Microbiol. 151 (1): 153-159.

https://doi.org/10.1016/j.vetmic.2011.02.039 PMid:21439740

6. Shitaye J.E., Tsegaye W., Pavlik I. (2007). Bovine tuberculosis infection in animal and human populations in Ethiopia: a review. Vet Med (Praha) 52 (8): 317-332.

7. Muller, B., Durr, S., Alonso, S., Hattendorf, J., Laisse, C.J., Parsons, S.D., Van Helden, P.D., Zinsstag, J. (2013). Zoonotic Mycobacterium bovisinduced tuberculosis in humans. Emerg Infect Dis. 19 (6): 899-908.

https://doi.org/10.3201/eid1906.120543

PMid:23735540 PMCid:PMC4816377

8. Gramatikovski, G., Stojanoski, B. (1985). Epidemiological situation of infectious diseases in Socialistic Republic of Macedonia 1927-1977. Veterinary Institute Skopje. (in Macedonian).

9. Nikolovski, G., Petrov, E.A., Cokrevski, S., Arsevska, E., Nikolovska, G. (2012) Bovine tuberculosis in cattle during the implementation of official control measures in Republic of Macedonia for the period 2007-2009. Slov Vet Res 49 (2): 79-87.

10. Food and Veterinary Agency of Republic of Macedonia (2007). Program for eradication of bovine tuberculosis. Official Gazette of Republic of Macedonia No. 22/2007. (in Macedonian).

http://fva.gov.mk/images/PROGRAMA_NA_TUBERKULOZATA_KAJ_GOVEDATA.pdf

11. OIE. (2009). Bovine tuberculosis. Manual for diagnostic tests and vaccines for terrestrial animals. http://www.oie.int/fileadmin/Home/eng/Health_ standards/tahm/2.04.07 BOVINE TB.pdf

12. Corner, L.A., Gormley, E., Pfeiffer, D.U. (2012). Primary isolation of Mycobacterium bovis from bovine tissues: conditions for maximising the number of positive cultures. Vet Microbiol. 156 (1): 162-171. https://doi.org/10.1016/j.vetmic.2011.10.016 PMid:22074859

13. Gormley, E., Corner, L.A., Costello, E., RodriguezCampos, S. (2014). Bacteriological diagnosis and molecular strain typing of Mycobacterium bovis and Mycobacterium caprae. Res Vet Sci. 97 Suppl, S30-43.

https://doi.org/10.1016/j.rvsc.2014.04.010

PMid:24833269
14. Pinsky, B.A., Banaei, N. (2008). Multiplex real-time PCR assay for rapid identification of Mycobacterium tuberculosis complex members to the species level. J Clin Microbiol. 46 (7): 2241-2246. https://doi.org/10.1128/JCM.00347-08 PMid:18508937 PMCid:PMC2446918

15. Domogalla, J., Prodinger, W.M., Blum, H., Krebs, S., Gellert, S., Muller, M., Neuendorf, E., Sedlmaier, F., Buttner, M. (2013). Region of difference 4 in alpine Mycobacterium caprae isolates indicates three variants. J Clin Microbiol. 51 (5): 1381-1388.

https://doi.org/10.1128/JCM.02966-12 PMid:23408688 PMCid:PMC3647898

16. Reddington, K., O’Grady, J., Dorai-Raj, S., Niemann, S., van Soolingen, D., et al. (2011). A novel multiplex Real-Time PCR for the identification of Mycobacteria associated with zoonotic tuberculosis. PLoS One 6 (8): e23481.

https://doi.org/10.1371/journal.pone.0023481

PMid:21858140 PMCid:PMC3153498

17. Rivière, J., Carabin, K., Le Strat, Y., Hendrikx, P., Dufour, B. (2014). Bovine tuberculosis surveillance in cattle and free-ranging wildlife in EU Member States in 2013: a survey-based review. Vet Microbiol. 173 (3): 323-331.

https://doi.org/10.1016/j.vetmic.2014.08.013 PMid:25205200

18. Schiller, I., Oesch, B., Vordermeier, H.M., Palmer, M.V., Harris, B.N., Orloski, K.A., Buddle,B.M., Thacker, T.C., Lyashchenko, K.P., Waters, W.R. (2010). Bovine tuberculosis. A review of current and emerging diagnostic techniques in view of their relevance for disease control and eradication. Transbound Emerg Dis. 57 (4): 205-220. https://doi.org/10.1111/j.1865-1682.2010.01148.x

19. Fitzgerald, S.D., Hollinger, C., Mullaney, T.P., Bruning-Fann, C.S., Tilden, J., Smith, R., Averill, J., Kaneene, J.B. (2016). Herd outbreak of bovine tuberculosis illustrates that route of infection correlates with anatomic distribution of lesions in cattle and cats. J Vet Diagn Invest. 28 (2): 129-132. https://doi.org/10.1177/1040638715626484 PMid:26965232

20. Pritchard, D.G. (1988). A century of bovine tuberculosis 1888-1988: conquest and controversy. Comp Clin Path. 99 (4): 357-399. https://doi.org/10.1016/0021-9975(88)90058-8

21. Whipple, D.L., Bolin, C.A., Miller, J.M. (1996). Distribution of lesions in cattle infected with Mycobacterium bovis. J Vet Diagn Invest. 8 (3): 351354.

https://doi.org/10.1177/104063879600800312 PMid:8844579 
Bovine tuberculosis: postmortem, microbiological and molecular study

22. Corner, L.A. (1994). Post mortem diagnosis of Mycobacterium bovis infection in cattle. Vet Microbiol. 40 (1): 53-63.

https://doi.org/10.1016/0378-1135(94)90046-9

23. Ministry of Agriculture, Food and Environment (2013). National Eradication Program for Bovine tuberculosis in Spain for 2013. (in Spanish)

http://rasve.magrama.es/Publica/Programas/NORMATIVA $\% 20 \mathrm{Y} \% 20 \mathrm{PROGRAMAS} \% 5 \mathrm{CPRO}$ GRAMAS\%5C2013\%5CTUBERCULOSIS\%20 BOVINA\%5CPROGRAMA\%20TB\%202013. PDF

24. European Commission Health \& Consumer Protection Directorate-General Veterinary and International Affairs Unit G5 - Veterinary Programmes. (2013). Working Document on eradication of Bovine tuberculosis in the EU. SANCO/10067/2013

25. Croatian Ministry of agriculture (2015). Annual order for animal protection from infectious and parasitic diseases for 2016. Official Gazette of Croatia No. 141/2015 (in Croatian)

http://narodne-novine.nn.hr/clanci/sluzbeni/2016_04_31_846.html

26. Boritsch, E.C., Supply, P., Honore, N., Seeman, T., Stinear, T. P., Brosch, R. (2014). A glimpse into the past and predictions for the future: the molecular evolution of the tuberculosis agent. Mol. Microbiol. 93 (5): 835-852.

https://doi.org/10.1111/mmi.12720

PMid:25039682

27. Mostowy, S., Cousins, D., Brinkman, J., Aranaz, A., Behr, M.A. (2002). Genomic deletions suggest a phylogeny for the Mycobacterium tuberculosis complex. J Infect Dis. 186 (1): 74-80.

https://doi.org/10.1086/341068

PMid:12089664

28. Huard, R.C., Lazzarini, L.C., Butler, W.R., van Soolingen, D., Ho, J.L. (2003). PCR-based method to differentiate the subspecies of the Mycobacterium tuberculosis complex on the basis of genomic deletions. J. Clin. Microbiol. 41 (4): 1637-1650. https://doi.org/10.1128/JCM.41.4.1637-1650.2003 PMid:12682155 PMCid:PMC153936

29. Warren, R.M., Gey van Pittius, N.C., Barnard, M., Hesseling, A., Engelke, E., de Kock, M., Gutierrez, M.C., Chege, G.K., Victor, T.C., Hoal, E.G., van Helden, P.D. (2006). Differentiation of Mycobacterium tuberculosis complex by PCR amplification of geno- mic regions of difference. Int. J. Tuberc. Lung Dis. 10 (7): 818-822. PMid:16850559
30. Pounder, J.I., Anderson, C.M., Voelkerding, K.V., Salfinger, M., Dormandy, J., Somoskovi, A., Heifets, L., Graham, J.J., Storts, D.R., Petti, C.A. (2010). Mycobacterium tuberculosis complex differentiation by genomic deletion patterns with multiplex polymerase chain reaction and melting analysis. Diagn. Microbiol. Infect. Dis. 67 (1): 101105.

https://doi.org/10.1016/j.diagmicrobio.2009.12.014 PMid:20227227

31. Rettinger, A., Broecki, S., Fink, M., Prodinger, W.M., blum, H., Krebs, S., Domogalla, J., Just, F., Gellert, S., Straubinger, R.K., Buttner M. (2015). The region of difference four is a robust genetic marker for subtyping Mycobacterium caprae Isolates and is linked to spatial distribution of three subtypes. Transbound Emerg Dis.

https://doi.org/10.1111/tbed.12438

PMid:26518998

32. Rodriguez, S., Bezos, J., Romero, B., de Juan, L., Alvarez, J., Castellanos, E., Moya, N., Lozano, F., Javed, M.T., Saez-Llorente, J.L., Liebana, E., Mateos, A., Dominguez, L., Aranaz, A. (2011). Mycobacterium caprae infection in livestock and wildlife. Spain. Emerg. Infect. Dis. 17 (3): 532-535. https://doi.org/10.3201/eid1703.100618 PMid:21392452 PMCid:PMC3165998

33. Munyeme,M.,Rigouts,L., Shamputa,I.C.,Muma,J.B., Tryland, M., Skjerve, E., Djønne, B. (2009). Isolation and characterization of Mycobacterium bovis strains from indigenous Zambian cattle using Spacer oligonucleotide typing technique. BMC microbiology 9 (1):1.

https://doi.org/10.1186/1471-2180-9-144

PMid:19619309 PMCid:PMC2719650

34. Proano-Pérez, F., Benitez-Ortiz, W., Desmecht, D., Coral, M., Ortiz, J., Ron, L., Portaels, F., Rigouts, L., Linden, A. (2011). Post-mortem examination and laboratory-based analysis for the diagnosis of bovine tuberculosis among dairy cattle in Ecuador. Prev Vet Med. 101 (1): 65-72.

https://doi.org/10.1016/j.prevetmed.2011.04.018 PMid:21645934

35. Nassar, A.F.C., Miyashiro, S., Oliveira, C.G., Pacheco, W.A. and Ogata, R.A. (2007). Isolation and identification of bovine tuberculosis in a Brazilian herd (São Paulo). Mem Inst Oswaldo Cruz. 102 (5): 639-642. https://doi.org/10.1590/S0074-02762007005000073 PMid:17710311

36. Shittu,A.,Clifton-Hadley, R.S.,Ely,E.R.,Upton,P.U., Downs, S.H. (2008). Factors associated with bovine tuberculosis confirmation rates in suspect lesions found in cattle at routine slaughter in Great Britain, 2003-2008. Prev Vet Med. 110 (3): 395- 404. 
37. Courcoul, A., Moyen, J.L., Brugere, L., Faye, S., Henault, S., Gares, H., Boschiroli, M.L. (2014). Estimation of sensitivity and specificity of bacteriology, histopathology and PCR for the confirmatory diagnosis of bovine tuberculosis using latent class analysis. PloS one 9(3): p.e90334. https://doi.org/10.1371/journal.pone.0090334 PMid:24625670 PMCid:PMC3953111

38. Duignan, A., Good, M., More, S.J. (2012). Quality control in the national bovine tuberculosis eradication programme in Ireland. Rev. Sci. Tech. Off. Int. Epiz. 31, 845-860.

https://doi.org/10.20506/rst.31.3.2166

39. Good, M., Duignan, A. (2011). An evaluation of the Irish Single Reactor Breakdown Protocol for 2005 to 2008 inclusive and its potential application as a monitor of tuberculin test performance. Vet. Microbiol. 151 (1): 85 -90.

https://doi.org/10.1016/j.vetmic.2011.02.029 PMid:21441002

40. De la Rua-Domenech, R., Goodchild, A.T., Vordermeier, H.M., Hewinson, R.G., Christiansen, K.H., Clifton-Hadley, R.S. (2006). Ante mortem diagnosis of tuberculosis in cattle: a review of the tuberculin tests, $\gamma$-interferon assay and other ancillary diagnostic techniques. Res Vet Sci. 81 (2): 190-210. https://doi.org/10.1016/j.rvsc.2005.11.005 PMid:16513150

41. Cvetnic, Z., Katalinic-Jankovic, V., Sostaric, B., Spicic, S., Obrovac, M., Marjanovic, S., Benic, M., Kirin, B.K., Vickovic, I. (2007). Mycobacterium caprae in cattle and humans in Croatia. Int J Tuberc Lung Dis. 11 (6): 652-658.

PMid:17519097

42. Beširović, H., Alić, A., Špičić, S., Cvetnić, Ž., Prašović, S., Velić, L. (2012). Bovine tuberculosis in Bosnia and Herzegovina caused by Mycobacterium caprae. Vet Arhiv. 82 (4): 341-349.

43. Boniotti, M.B., Goria, M., Loda, D., Garrone, A., Benedetto, A., Mondo, A., Tisato, E., Zanoni, M., Zoppi, S., Dondo, A., Tagliabue, S., Bonora, S., Zanardi, G., Pacciarini, M.L. (2009). Molecular typing of Mycobacterium bovis strains isolated in Italy from 2000 to 2006 and evaluation of variablenumber-tandem-repeats for a geographic optimized genotyping. J Clin Microbiol. 47 (3): 636-644.

https://doi.org/10.1128/JCM.01192-08

PMid:19144792 PMCid:PMC2650904
44. Prodinger, W.M., Brandstätter, A., Naumann, L., Pacciarini,M.,Kubica, T.,Boschiroli,M.L.,Aranaz,A., Nagy, G., Cvetnic, Z., Ocepek, M., Skrypnyk, A., Erler, W., Niemann, S., Pavlik, I., Moser, I. (2005). Characterization of Mycobacterium caprae isolates from Europe by mycobacterial interspersed repetitive unit genotyping. J Clin Microbiol. 43 (10): 49844992.

https://doi.org/10.1128/JCM.43.10.4984-4992.2005 PMid:16207952 PMCid:PMC1248478

45. Sahraoui, N., Muller, B., Guetarni, D., Boulahbal, F., Yala, D., Ouzrout, R., Berg, S., Smith, N.H., Zinsstag, J. (2009). Molecular characterization of Mycobacterium bovis strains isolated from cattle slaughtered at two abattoirs in Algeria. BMC Vet Res. 5 (1): 4.

https://doi.org/10.1186/1746-6148-5-4 PMid:19173726 PMCid:PMC2640374

46. Zeng, W., Zhang, Y., Zhao, X., Huang, G., Jiang, Y., Dong, H., Li, X., Wan K., He, C. (2013). Occurrence of non-tuberculous mycobacteria species in livestock from northern China and first isolation of Mycobacterium caprae. Epidemiol Infect. 141 (7): 1545-1551.

https://doi.org/10.1017/S0950268812003020 PMid:23298678

47. Shitaye, J.E., Getahun, B., Alemayehu, T., Skoric, M., Treml, F., Fictum, P., Vrbas, V., Pavlik, I. (2006). A prevalence study of bovine tuberculosis by using abattoir meat inspection and tuberculin skin testing data, histopathological and IS6110 PCR examination of tissues with tuberculous lesions in cattle in Ethiopia. Vet Med (Praha). 51 (11): 512-522.

48. European Food and safety Authority. (2014). The European Union Summary Report on Trends and Sources of Zoonoses. Zoonotic Agents and Foodborne Outbreaks in 2012. EFSA Journal 12 (2): 3547 (pp 312).

49. Rodriguez, E., Sanchez, L.P., Perez, S., Herrera, L., Jimenez, M.S., Samper, S., Iglesias, M.J. (2009). Human tuberculosis due to Mycobacterium bovis and M. caprae in Spain, 2004-2007. Int J Tuberc Lung D. 13 (12): 1536-1541. PMid:19919773 